\title{
STATE CONTROL OF INTERSTATE AIR POLLUTION
}

\author{
Lewis C. GreEN*
}

It is a truism that air contaminants do not respect political boundaries. It follows that in airsheds which include parts of more than one state, and especially in our large interstate metropolitan centers, air contaminants emitted in one state frequently cross the state boundary, and contribute to a condition of air pollution in the receiving state. Indeed, the contaminants may cross back and forth many times, perhaps undergoing chemical changes in the meantime.

How can the receiving state protect itself, or its citizens, from such contaminants emitted in a neighboring state? So far, no state has succeeded in doing so. Some possibilities are considered below.

For convenience, it may be useful to consider this question in three different contexts: (I) the power of the receiving state, under traditional constitutional theory; (2) opportunities afforded to receiving states under federal legislation; and (3) the possibility of control achieved through an interstate compact.

The Constituttonal Extent of the Power of the Recerving State

There are various procedures by which an intrastate polluter may be curbed. The state or local government might enforce a statute or ordinance controlling air pollution. A private party might bring an action for nuisance, trespass, negligence, or other common law remedies. ${ }^{1}$ Such efforts will encounter various difficulties, in theory and in proof, beyond the scope of this paper.

The pursuit of the same remedies to curb the emission of air contaminants emitted in another state will encounter additional obstacles. First, one must obtain jurisdiction over the defendant. In the case of a large corporation with a place of business within the receiving state, this will pose no problem. In other cases, this may be a serious obstacle. In the case of a localized nuisance emission, immediately adjacent to a state boundary, it might be possible to present scientific proof that the contaminant complained of, in a reasonably identifiable form, crosses the state boundary and itself causes some harm or discomfort to the plaintiff. With proof that simple, it is highly arguable that the United States Constitution would not preclude the court of the receiving state from asserting jurisdiction over the defendant,

- A.B. r945, LL.B. 1950, Harvard University. Member of firm of Green, Hennings, Henry \& Arnold, St. Louis, Mo. Chairman, Missouri Air Conservation Commission.

${ }^{1}$ See Juergensmeyer, Control of Air Pollution Through the Assertion of Private Rights, I967 DukE L.J. Ir26. 
and some of the modern long-arm statutes would appear to provide a mechanism for doing so. ${ }^{2}$

But the proof will rarely be that simple. By and large, it will be impossible to prove that a specific contaminant, emitted from a specific plant, identifiable in form, itself crossed the state boundary. The intermingling and interaction of the contaminants with one another in the ambient air, and the changing chemical composition of many of them, would usually preclude such a specific finding. The plaintiff could rarely prove more than that the contaminant complained of entered into the ambient air over the entire interstate region, and contributed to a condition of air pollution throughout that region.

Even if the individual contaminant could be specifically traced across the state line, it would still be exceedingly difficult, and usually impossible, to prove that the specific contaminant itself caused harm to the plaintiff; the most that could usually be proved would probably be that the air pollution in the receiving state, to which the contaminant contributed, caused harm in the receiving state. It may be predicted that this thin nexus between the defendant's emission and the plaintiff's injury will some day be sufficient to sustain the assumption of jurisdiction by the courts of the receiving state, but it is questionable whether most courts are ready to go this far.

Assuming that jurisdiction can be obtained over the defendant, at least in a suit for an injunction, one may still encounter the objection that the court of the receiving state will not order the defendant to do, or refrain from doing, something in another state, beyond the supervisory power of the court. Discussion of that issue is beyond the scope of this article. ${ }^{3}$

A possible variant of the traditional lawsuit is a suit by the receiving state, as parens patriae, against the polluter or against the state where the polluter is located, on the theory that the emitting state has wrongfully permitted its citizens to harm the plaintiff state and its citizens.

A suit by the state as parens patriae, in the courts of the receiving state, or the federal courts located within the receiving state, would not appear to stand on a much better footing than a suit by a private citizen, in overcoming the traditional jurisdictional and equity obstacles noted above. However, if it is necessary to show a causal relationship between the offending emission and some harm to the plaintiff, either as a matter of jurisdiction over the defendant, or as a matter of the plaintiff's standing, the state as parens patriae might be on sounder footing than the private citizen, in complaining that the offending emission from a neighboring state contributes to a generalized condition of pollution in the receiving state, which condition is generally offensive and harmful to the citizens of the receiving state.

\footnotetext{
${ }^{2}$ Cf., e.g., Gray v. American Radiator \& Standard Sanitary Corp., 22 Ill.2d 432, 176 N.E.2d 761 (I961); Restatement of Conflict of Laws $\$ 377$ (1934; Supp. 1967); A. Ehrenzweig, Conflict of Laws ir6 (I962); H. Goodrich, Conflict of Laws I26 (4th ed. E. Scoles I964).

${ }^{3}$ See, e.g., H. Goodrich, supra note $2, \$ 78$.
} 
An alternative would be a suit by the receiving state as parens patriae, either against the offending polluter in the state or federal courts of the emitting state, or against the emitting state in the original jurisdiction of the United States Supreme Court. ${ }^{4}$ The possibility of such litigation is exceedingly remote, and has become even more remote as a result of the creation of administrative remedies better designed to deal with these technical problems, in the Clean Air Act of 1963.

Under favorable circumstances, it would be possible for a state or municipal government to bring other pressures, outside the judicial or administrative systems, to bear upon an offending polluter. For example, government contracts could be denied; the charter of a domestic corporation could be forfeited, and the authority of a foreign corporation to do business in the receiving state could be revoked; ${ }^{5}$ or access to the courts of the receiving state could be denied. Such sporadic pressures could hardly develop a comprehensive program to control emissions from numerous sources in an interstate metropolitan area.

\section{II}

\section{FEDeral Legislation}

\section{A. The Clean Air Act of 1963}

The first major congressional legislation dealing with air pollution was the Clean Air Act of $x 963{ }^{6}$ In that act, Congress discreetly, and perhaps wisely, adopted the position that "the prevention and control of air pollution at its source is the primary responsibility of States and local governments," and announced its purpose "to encourage and assist the development and operation of regional air pollution control programs." Nevertheless, Congress recognized that there might be some instances where one state might be dissatisfied with a lack of control in a neighboring state, and in section 105 of the act provided an administrative remedy for the complaining state. $^{8}$

The administrative proceeding may be commenced by a formal request from the governor of the complaining state, or a state air pollution control agency, to be lodged with the Secretary of Health, Education, and Welfare. A complaint lodged by a municipality may be sufficient to persuade the Secretary to begin an abatement proceeding, but will not invoke a mandatory administrative process unless it has the concurrence of the governor and the state air pollution control agency in which the municipality is situated.

From that point on, the proceeding is out of the control of the complaining state,

Cf. Missouri v. Illinois, I80 U.S. 208 (I90I); 200 U.S. 496 (I906).

'Cf. N.Y. GEN. CoRP. Law $\$ \$ 230-32$ (McKinney I943).

${ }^{\circ} 42$ U.S.C. $\$ \$ 1857_{--1857 l}(1964)$, as amended, 81 Stat. 485 (1967).

${ }^{7} 42$ U.S.C. $\$ \$ 1857$ (a) (3), (b) (4) (1964).

s U.S.C. $\$ 1857$ d ( 1964$)$. In May 1968, the eighth such administrative proceeding was announced. 6 Alr/Water Pollution Report 169 (May 20, 1968). 
although that state participates in the proceeding to a greater extent, in some respects, than in an adversary judicial proceeding. The Secretary calls a conference of the complaining agency or agencies, the air pollution control agency, if any, of each state, or for each area, concerned, and any interstate air pollution control agency affected. Under the 1963 Act, any alleged polluters interested in the proceedings were not eligible to attend the conference as of right, but could be invited by the government authorities eligible to attend.

The conference is presided over by an appointee of the Secretary, who need not have legal or judicial experience. All parties who appear are permitted to present any witnesses or evidence they desire. Experience indicates that rules of evidence are foreign to the proceeding. Witnesses are not sworn, and may not be crossexamined, but the presiding officer permits what he regards as "clarifying questions."

Following the conference, the Secretary prepares what the statute calls "a summary of conference discussions," and may issue recommendations to the appropriate control agencies as to necessary remedial action. In practice, he has issued such recommendations following the opening session of a conference, without waiting for the conclusion of the entire conference, which may be continued over a matter of years. In practice, also, he has directed his recommendations to polluting industries themselves, as well as to control agencies. In executive session, the parties to the proceeding have an opportunity to suggest to the presiding officer what the Secretary's summary and recommendations should be, before they are issued.

In making any such recommendations, the Secretary must allow at least six months for the taking of recommended remedial action. If, at the conclusion of the period allowed, the Secretary is dissatisfied with progress being made, he calls a "public hearing" before a hearing board of five or more persons appointed by the Secretary. Each state affected may choose one of the five members; each federal department which the Secretary determines to have a substantial interest in the matter may choose one member; one member must be representative of any appropriate interstate air pollution agency; and a majority must be persons other than officers or employees of HEW.

The proceedings of the hearing board are apparently expected to be more formal

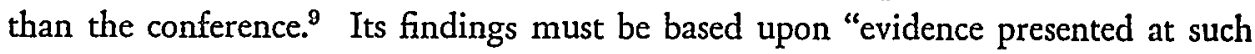
hearing." If the hearing board finds that pollution is occurring and "effective progress toward abatement thereof is not being made," it recommends to the Secretary "reasonable and suitable" measures to abate the pollution.

The Secretary apparently has no power to alter the "recommendations" of the hearing board, but he can allow a reasonable time for compliance (not less than six months). If action reasonably calculated to secure abatement of the pollution within the time specified by him is not taken, the Secretary may request the Attorney Gen-

\footnotetext{
- Procedures proposed by the Secretary, and followed in the only hearing held so far, are published at 32 Fed. Reg. 5514 (1967).
} 
eral to bring a suit on behalf of the United States to abate the pollution. The transcript of the proceedings before the hearing board, and the board's recommendations, must be received in evidence in such a suit, and the court may receive such further evidence as it deems proper. The court has jurisdiction to "enter such judgment, and orders enforcing such judgment, as the public interest and the equities of the case may require.",aa

In this way the complaining state may ultimately invoke the judicial process to abate pollution in a neighboring state. However, the course of the proceedings is entirely beyond the control of the complaining state, lying within the discretion of the Secretary at every stage. Moreover, the various time periods written into the statute establish a theoretical minimum of one year and six months from the date of the complaint to the initiation of the judicial process; a more realistic estimated minimum time lag would be two years.

The foregoing administrative procedure remains available under the Air Quality Act of $196 \%{ }^{10}$ The only changes in the procedures are found in section I08(d) (2) and $\operatorname{Ios}(f)(I)$. The only change which may be of substantial significance is the requirement that, at both the conference and the proceedings before the hearing board, "interested parties" must be given an opportunity to present evidence. The significance of this language is not clear. It may be designed to insure the right of an alleged polluter to be heard, even though he is not invited to appear by his state or local government. On the other hand, the use of the word "parties" rather than "persons" would appear to restrict the benefits of this guarantee to those persons invited by the governmental agencies. ${ }^{11}$

\section{B. The Air Quality Act of 1967}

The second principal piece of federal legislation on the subject of air pollution was the Air Quality Act of 1967 , cited above. In I 967 the Congress clearly maintained its position that the control of air pollution "is the primary responsibility of States and local governments," and maintained its purpose to encourage the development of "regional air pollution control programs." At the same time, Congress, as noted above, retained the federal abatement powers outlined above. In addition, sections I06 and 107 of the act, together with section ro8(c), provide an entirely new procedure for dealing with interstate air pollution problems, if they occur in what the act calls "air quality control regions." The Secretary of HEW is empowered to

\footnotetext{
on The first suit to be filed pursuant to this section was United States v. Bishop Processing Co., No. 19274 (D. Md., filed March 7, 1968). On July I6, I968, the District Court upheld the validity of the statute and the administrative process, ruling that the findings and recommendations of the hearing board should be received in evidence not as evidence of disputed facts, but only as recommendations respecting the public interest and the equities of the case. 37 U.S.L.W. 2062.

${ }_{10}^{81}$ Stat. 485 , amending 42 U.S.C. $\$ \$ 1857-1857$ (1964).

${ }^{11}$ See S. REP. No. 403, 90th Cong., Ist Sess. 30 (I967); H.R. ReP. No. 728, 90th Cong., Ist Sess. 27 (1967); Bermingham, The Federal Government and Air and Water Pollution, 23 Busrness Law. 467, $4^{8} 3-84$ (1968).
} 
prescribe "air quality criteria," "air quality standards," and "recommended control techniques" for such regions. The role of the complaining state in this procedure is even more shadowy than in the abatement proceedings under the Clean Air Act of 1963 -so shadowy that the new proceedings do not merit analysis in a paper on state control of air pollution emanating from another state. Suffice it to say that the procedures for bringing into court a recalcitrant polluter, located in a state which does not energetically implement the Secretary's recommendations, not only are outside the control of the neighboring state, but also are even more time-consuming than the abatement procedures under the 1963 Act, probably requiring at least three or four years, and more likely five or ten years, from the enactment of the Act through judicial action. Moreover, the law as finally passed is an outstanding example of wretched draftsmanship, leaving in a state of utter confusion the fundamental question of whether, and when, effective emission standards applicable to individual industrial plants may be promulgated by the Secretary.

\section{III}

\section{INTERSTATE COMPACTS}

If the state, rather than the federal government, is going to achieve any significant degree of control over air pollution emanating from a neighboring state, it would appear that such control will have to be developed through the device of the interstate compact. Both the 1963 and 1967 federal laws, in section $102(a)$, directed the Secretary of HEW to encourage the making of agreements and compacts between states for the prevention and control of air pollution. However, section I02(c) provides that no such agreement or compact may become effective unless it has been approved by Congress. The 1967 Act further provides, as to compacts entered into between states after enactment of the 1967 Act, that such a compact should not provide for participation by a state which is not included (in whole or in part) in the "air quality control region" which the compact deals with.

At this writing, no interstate air pollution control compact has won the approval of Congress. It remains to be seen whether the interstate compact will prove to be an effective device by which a state may achieve adequate control of air pollution emanating from a neighboring state.

\section{A. Historical Development of the Interstate Compact}

Consideration of the utility of the interstate compact in solving interstate air pollution problems may be enlightened by a thumbnail sketch of our experience with the compact device in other contexts. Interstate compacts have their roots deep in our colonial history. Most of the colonial charters were necessarily vague in their geographcial terms, dealing as they did with strange territory which had been poorly 
surveyed. As the populations of the bordering colonies came into conflict, territorial disputes between the colonies became commonplace. A common method of resolving such disputes was negotiation of an agreement by the two colonies, subject to approval by the Crown.

At the time of the adoption of the Constitution, there were existing controversies involving eleven states respecting their boundaries. The framers of the Constitution were familiar with the history of such disputes, and the procedures for settling them. This was the background in which the framers wrote: 12 "No State shall, without the Consent of Congress ... enter into any Agreement or Compact with another State, or with a foreign Power ...." A search for contemporaneous articulation of the purpose of this clause is not rewarding. It appears that there is no reference to this clause in the records of the Constitutional Convention, or in the Federalist papers. ${ }^{13}$

From 1789 until the I920s, the interstate compact was used exceedingly little. Until that time, every interstate compact (with one exception) concerned boundary matters. In the Ig20s, however, the first compacts were adopted to create administrative machinery for continuous joint administration of a regional problem. The landmark was the New York Port Authority Compact of $1921,{ }^{14}$ creating the Port Authority which still exists today, with full responsibility for the planning and administration of the transportation problems of the Port of New York, divided by the New York-New Jersey state line. Other compacts in the rgzos provided machinery for allocation of waters, and operation of bridges, tunnels, and the like.

A new interest in the interstate compact clause was kindled in the $x 930$ s, arising principally from two sources. First, in I925 Felix Frankfurter and James Landis published their classic treatise on the interstate compact clause, calling for

The imaginative adaptation of the compact idea ... in the solution of problems presented by the growing interdependence, social and economic, of groups of States forming distinct regions .... The overwhelming difficulties confronting modern society must not be at the mercy of the false antithesis embodied in the shibboleths "States-Rights" and "National Supremacy." We must not deny ourselves new or unfamiliar modes in realizing national ideals. Our regions are realities. Political thinking must respond to these realities. ${ }^{15}$

A second factor giving impetus to the increased use of the compact clause was the emergence of a marked trend toward centralization of governmental authority

\footnotetext{
${ }^{12}$ U.S. Const. art. I, $\S$ Io.

${ }^{19}$ The classic authority on the history of the interstate compact clause prior to 1925 is Frankfurter \& Landis, The Compact Clause of the Constitution-A Study in Interstate Adjustments, 34 YALE L.J. 685, 69x-708 (1925). See also Grad, Federal-State Compact: A New Experiment in Cooperative Federalism, $6_{3}$ Colum. I. Rev. 825, 834 (I963).

16 Act of Aug. 23, 1921, 42 Stat. I74; N.J. Laws I921, ch. 151, p. 412; N.Y. Laws 1921, ch. 203, p. $84 \mathrm{r}$.

${ }^{16}$ Frankfurter \& Landis, supra note 13 , at 729 .
} 
and responsibility in Washington. It was in the r930s that the Supreme Court finally changed its course, and upheld the power of the federal government to regulate many matters of social and economic concern which had previously been thought to be the exclusive domain of the state governments. As the need for governmental action in these areas became increasingly clear, and the fear of centralization of power in Washington increased simultaneously, a number of persons followed Mr. Frankfurter's advice, and looked to the compact clause, in the hope of forestalling federal intervention.

In subsequent years, the compact device has been used with increasing frequency, and directed toward a number of administrative, or proprietary, concerns. Compacts now in effect are directed toward such diverse subjects as supervision of parolees and probationers, recommending common procedures for oil and gas conservation, and for conservation of fisheries, administration of public transportation and flood control, development of common regional institutions such as the Southern Regional Education Compact, mutual aid in fighting forest fires, and a host of other subjects.

Of particular interest is the use of the compact to provide joint governmental operations in an interstate metropolitan area. It is said that thirty of the 216 metropolitan areas in the United States, containing about twenty-two per cent of the population, straddle state lines. ${ }^{16}$ Nevertheless, from the date of the New York Port Authority Compact in I92I, it was not until I949 that a similar joint agency was established in any other interstate metropolitan area; that is the Bi-State Development Agency in the St. Louis area. ${ }^{17}$ Regrettably, the most significant goals of BiState have never been realized. That compact's contribution to the development of this governmental device was its designation of Bi-State as the general planning agency for the entire area. For one reason or another, Bi-State has never assumed that responsibility.

While the use of the compact device has been slowly increasing in such administrative or proprietary areas, there have been very few experiments with this device in the field of regulation. Several compacts have created commissions with authority to abate water pollution, in the New York-New Jersey-Connecticut area, and in the Ohio and Delaware River basins. In 1953 New York and New Jersey created the Waterfront Commission to regulate undesirable labor-management practices, racketeering, and violence along the New York waterfront, outlawing the "shape up" hiring system and other practices. In I959 Maryland and Virginia created a

\footnotetext{
${ }^{10}$ Dixon, Constitutional Bases for Regionalism; Centralization; Interstate Compacts; Federal Regional Taxation, 33 Geo. Wash. L. Rev. 47, 56 (r964); J. Winters, Interstate Metropolitan Areas 2-4 (Legislative Research Center, University of Michigan Law School, r962). Cf. Leach, Interstate Authorities in the United States, 26 LAw \& Contenp. Prop. 666, 680 (196I); Edelman, Legal Problems of Interjurisdictional Air Pollution Control, I3 J. AIR Pollution Control Ass'N 3 Io (I963).

${ }^{17}$ Mo. REv. STAT. \$70.370 (1959).
} 
compact commission with broad powers to regulate the disputed fisheries of the Potomac River. ${ }^{18}$

More recently, the first efforts have been made to direct the compact device to the field of air pollution. Several years ago the Interstate Sanitation Commission was given jurisdiction to deal with air pollution in the New York-New Jersey area, but its powers were limited to study and recommendations, and it was given no direct abatement powers. ${ }^{19}$ Its success can be measured by the fact that a federal abatement action is now underway in New York, and the two states have agreed that a new compact is needed, with broad geographical jurisdiction and abatement powers.

\section{B. Evaluation}

As devices to settle boundary disputes, the compacts have clearly been useful. However, as devices to establish permanent administrative machinery, their value is less clear. They have been widely criticized as characteristically indecisive and ineffective, as inflexible, and as lacking effective political control or responsibility. ${ }^{20}$ It has been said that the states are unwilling or incapable of discharging adequately their responsibilities in the formulation of major policies. Professor Dixon sadly describes "the sorry past record of interstate compact agencies in regard to their responsiveness and responsibility."21 More bluntly, Professor McKinley describes the interstate compact commissions as "cumbersome, jerry-built structures lacking in region-wide political responsibility, parasitic on national finance, and negative or unduly dilatory in decision-making." 2

As to regulatory functions, one can point to virtually no achievement, and very little effort. A few water pollution compacts, a waterfront racketeering compact; and a fisheries compact represent the most significant efforts in this direction. ${ }^{23}$ Few citizens are satisfied with the cleanliness of the Ohio or Delaware Rivers, or New York Harbor. The present writer was recently informed that there were two pending federal abatement actions to clean up tributaries of the Ohio River, which the Ohio River Commission had failed to clean up. ${ }^{24}$

\footnotetext{
${ }^{28}$ Discussion of these compacts may be found in many sources, including F. ZIMOMERMan \& $M$. Wendel, The Law and Use of INTerstate Compacts 46-49 (Council of State Governments, I966).

${ }^{10}$ N.Y. Pub. Healtm Law $\S \mathrm{r} 299 l$, repealed in 1967 by passage of Mid-Atlantic States Air Pollution Control Compact (see note 35 infra); N.J. STAT. ANN. \$\$3I:I9A-I-32:19A-9 (repealed in I967).

${ }^{30}$ E.g., Engelbert, Federalism and Water Resources Development, 22 LAw \& CoNTEMP. ProB. 325 (x957); Forer, Water Supply: Suggested Federal Regulation, 75 HAnv. L. Rev. 332, 342-43 (rg6r). ${ }_{21}$ Dixon, supra note 15, at 77.

${ }^{22}$ McKinley, The Management of Water Resources Under the American Federal System, in FeDERALISM: Mature and Earergent 328, 347 (McMahon ed. 1962).

${ }^{28}$ In $196 \mathrm{r}$, Leach observed that there were only six true interstate authorities in the United States, and "except for the two port authorities, none of them amount to much." Leach, supra note 15, at 666.

${ }^{2}$ Cf. Cohen, Interstate Compacts-An Evaluaion, I7 J. Air Polzution Controu Ass'n 676, 677 (I967), reprinted in Hearings on Air Pollution Compacts (Air Pollution-1968) Before the Subcomm. on Air and Water Pollution of the Senate Comm. on Public Works, goth Cong., $2 \mathrm{~d}$ Sess., pt. I, at I93, I95 (I968).
} 


\section{Alleged Deficiencies of Existing Compacts}

Why have these compacts failed to achieve more? Partly, it is sometimes suggested, because the states which enter these compacts really do not want to achieve more, their principal objective being simply to establish a barrier between their regional problems and federal control. ${ }^{25}$ And partly because (either inadvertently or by design) they are not calculated to foster effective action.

Many of the compacts by their very terms have shackled the compact commissions, with the result of discouraging, if not preventing, effective action. It is sometimes provided that no action can be taken by the compact commission without the approval of a majority of the members from every one of the participating states, or at least from the state to be affected by the action to be taken. ${ }^{28}$ Often it is provided that a quorum requires the presence of a majority of the members from each state. In the case of a two-state compact, with each state voting as a unit, the probability of an impasse is ever present. Even in a multi-state compact, it is no surprise that, as Mr. Grad has pointed out, "the natural drift is in the direction of action by unanimity, since no member wishes to antagonize any other for the future when his state's pet project may be up for a vote."27 Moreover, the compact commission is generally dependent upon the good will of the legislature of each of the states for its annual or biennial appropriations. Inevitably, with this kind of compact any possible action is geared to the lowest common denominator, the minimal action on which everybody is willing to agree. ${ }^{28}$ As Senator Muskie recently observed at the St. Louis hearings of his subcommittee on air and water pollution, he knows of no instance in which an interstate compact commission has taken enforcement action in the state of a dissenting governor. ${ }^{20}$ In short, effective action is sacrificed on the altar of unanimity. The caravan plods along at the pace of the slowest camel.

A second major reason frequently advanced for the "sorry record" of the compact clause is the lack of political responsiveness. ${ }^{30}$ By and large, the members of the compact commission are appointed. They do not run for election, and cannot easily be held accountable by the voters. The absence of accountability to the voters is highlighted by the common practice of giving equal voting strength to each state, regardless of the relative numbers of persons affected by the compact.

\footnotetext{
${ }^{25}$ E.g., W. Leuchtenberg, Flood Control Polimics 250 (1953).

${ }^{96}$ For example, note Senator Douglas' objections to the proposed Illinois-Indiana compact. xI2 CoNo. Rec. I4, 160-6I (daily ed. June 30, 1966). See LeUchtenberg, supra note 25, at 25I; Hearings, supra note 24. Cf. Hart, Creative Federalism: Recent Trends in Regional Water Resources Planning and Develop. ment, 39 Colo. L. Rev. 29, 44 (1966).

"Grad, supra note 13, at 853. See Draper, Regional Planning, in Planning for America 516 (G. Galloway ed. r94r).

" See V. Thursby, Interstate Cooperation, A Study of the Interstate Conspact 136 (1953).

"Hearings on S. 780 (Air Pollution-1967) Before the Subcomm. on Air and Water Pollution of the Senate Comm. on Public Works, 90th Cong., rst Sess., pt. 2, at 995 (I967).

${ }^{30}$ E.g., Dixon, supra note 15 , at 72-75.
} 
D. Suitability of the Interstate Compact for the Control of Air Pollution

What about air pollution control as the subject of an interstate compact? Air pollution control requires continuous day-to-day enforcement of detailed regulations, imposed upon thousands of sources in a large metropolitan area. No matter how tightly the regulations may be drawn, it seems inevitable that a great deal of discretion must be vested in the enforcement officials. A control program can be made or broken by the energy and enthusiasm, or the lethargy and reluctance, of the enforcement officials. The everyday decisions of when, and where, and how often, to take tests and samples, under what circumstances to grant variances, and what control devices or systems to encourage or approve, are the heart of an enforcement program.

Moreover, the subject is a very technical one. The average citizen will ordinarily be unable to form any judgment on the desirability of a given regulation, or a given variance or abatement order. He can only form a judgment on the over-all quality of the air, and cannot easily pinpoint lax enforcement of stringent regulations. As Dr. Forer has said of the relatively simple problems of water allocation compacts, "The far-reaching nature of the decisions, and the complexity of the facts, the hypotheses, and the evidence upon which such decisions must inevitably be based, preclude the local town-meeting type of decision-making to which lipservice is so often paid."

Affecting as it does all industries throughout the area, an air pollution control program brings into play the economic rivalries between the jurisdictions, on a much broader scale than the rivalries confronted in the fisheries compacts. Uniformity of regulations, and uniformity of enforcement, are essential throughout the area, not only to insure coordinated planning, and not only as a matter of fairness to the taxpayer who pays for air pollution control in his own county or town, but also as a matter of equity, to prevent industrial pirating. And all of these factors are brought to bear upon one another, so that the natural suspicions and mistrust characteristic of a single metropolis divided by a state line are enhanced, and are focused upon the possibility of lax enforcement and industrial pirating.

In short, it would appear that air pollution control is an extremely difficult subject to handle by way of an interstate compact, probably much more difficult than the subject of labor racketeering, or of fisheries. It is in many ways analogous to the problem of water pollution, but a good deal more difficult even than that problem, because of the multiplicity of sources and the difficulty of tracing contaminants back to their sources, and the broader range of economic competition.

Thus it seems fair to conclude not only that the development of the interstate compact clause for regulatory purposes presents a "sorry record," but also that air pollution control is an extraordinarily difficult and sensitive problem to present to two contiguous states for solution. Many of the people most impatient for effective

\footnotetext{
${ }^{31}$ Forer, supra note 19, at 341 .
} 
air pollution control conclude that the record of the interstate compact is so dismal that it deserves no further consideration. They would have the federal government proceed forthwith to do the job of cleaning up the air, at least in these regional interstate areas. To some extent this conclusion is reflected in that part of the Air Quality Act of $x 967$ which authorizes the Secretary of HEW to designate air quality control regions, and prescribe standards for them.

Nevertheless, other persons believe that a further effort should be made to develop a really effective compact. As Professor Dixon says,

We are teetering on the brink of a totally centralized federal system, under which many sub-national problems such as metropolitan mass transit, stream pollution and water supply, and air pollution, may pass by default to the federal government. $^{32}$

Experience raises doubts that Washington can effectively regulate all these problems throughout the many metropolitan areas of the country. If the country is to thrive and prosper, our federal system, it is urged, must be used to develop local initiative, local leadership, and local responsibility.

The "sorry record" of the compact clause, while discouraging, does not necessarily preclude such an effort. At the 1966 National Air Pollution Conference in Washington, Vice President Humphrey and Senator Muskie both called for the development of "fresh thinking" to develop effective interstate air pollution control compacts. ${ }^{33}$ As Mr. Grad has said:

An emphasis on "states" rights" and a narrow emphasis on "local home rule" misses the mark entirely. An approach to problems of regional dimensions can only be in terms of larger units-and this leaves only two major alternatives: federal action, or interstate action with federal participation when necessary. . . . Whether such a system of federal-state compacts will succeed in the effective resolution of broad, region-wide problems, while bridging the gap in effective state participation in the formulation of policy, will depend on the states' maturity to assume this new role. The states will fail in this effort if they regard compacts like the Delaware River Basin Compact as an affirmation of a narrow concept of state sovereignty. They may succeed if, along with the assertion of legitimate interests of their own, they regard their role as historic, independently functioning parts of a regional polity and of a national union..$^{84}$

\section{E. Minimal Criteria for an Effective Interstate Air Pollution Control Compact}

In March of 1968 Senator Muskie's subcommittee on air and water pollution held hearings on the proposed Illinois-Indiana, Mid-Atlantic, and Ohio-West Virginia air pollution control compacts. ${ }^{35}$ At those hearings Dean W. Coston, Deputy Under-

\footnotetext{
${ }^{32}$ Dixon, supra note 16 , at 87 .

${ }^{83}$ Proceedings: The Third National Confenence on Ajr Polzution 7, 598 (Public Health Service Pub. No. 1649, 1967).

${ }^{86}$ Grad, supra note 13 , at 851, 854-55.

${ }^{85}$ Hearings on Air Pollution Compacts (Air Pollution-1968) Before the Subcomm. on Air and
} 
secretary of the Department of Health, Education and Welfare, on March 26, listed six criteria recommended by the Department for determining whether a proposed compact would provide an effective basis for action to deal with air pollution, and would be consistent with the Air Quality Act of $1967 .^{30}$ His proposed criteria were as follows:

I. Only states included in whole or in part in a given air quality control region should participate in a compact dealing with that region, as provided by section I02(c) of the Act, but all of those states should be parties to the compact.

2. Federal representation on interstate compact commissions is desirable, but federal voting membership is not.

3. Each participating state should have one vote on a compact commission, regardless of the number of members of the commission provided by each state.

4. A compact commission should have broad powers of air monitoring, regulation, and enforcement.

5. The compact should provide a meaningful definition of air pollution; a compact which permits action only upon a showing that an identifiable contaminant has crossed a state line and actually inflicted identifiable injury upon some person is inadequate.

6. An interstate compact should enhance the ability of member states to carry out their functions under the Clean Air Act.

Except for the matter of voting participation by the federal government, all of these points appear to be well taken. The sixth point is rather obscure, and the matter of voting by states or by individual members appears to be legitimately debatable, but the other points are beyond question.

Perhaps the most fundamental of these points is the inclusion in the compact of direct authority in the compact commission to set standards and to enforce them. It would appear that there is no other way to achieve the essential uniformity of regulation and enforcement. ${ }^{37}$ Such authority was contained in the Mid-Atlantic compact, and was also provided in the Kansas-Missouri compact passed by the

Water Pollution of the Senate Comm. on Public Works, goth Cong., $2 \mathrm{~d}$ Sess., pt. I (I968). The three proposed compacts are reprinted in the hearings volume: S.2350 (Ohio-West Virginia); S.J. Res.95 (MidAtlantic States); S.470 (Illinois-Indiana).

${ }^{80} I d$. at $46 \mathrm{r}$.

${ }^{87} \mathrm{An}$ interesting experiment is the proposal of various authorities in the so-called "Quad City" area (Rock Island County, Illinois and Scott County, Iowa) to adopt the "Quad City Area Regional Air Pollution Control Charter." The draft would create a single interstate air pollution control authority, with primary regulatory and enforcement powers. Wilson P. Burns, Chairman of the Joint Air Pollution Control Committee of the Quad Cities' Chambers of Commerce, states that the intention is to have both counties, and the cities within the two counties, approve the charter. (Mr. Burns is also Director, Foundries, at Deere \& Company, Moline, Illinois.)

The writer's understanding is that local authorities do not intend to seek the approval of Congress. One presumes that they have communicated with the attorneys general of the two states, and have concluded that congressional approval is not necessary, notwithstanding the requirement of federal law that agreements or compacts between states for the prevention and control of air pollution must be approved by Congress before becoming effective. 
Missouri General Assembly in 1967 , but rejected by the Kansas General Assembly. ${ }^{88}$

To the extent that Mr. Coston was expressing opposition to a federal vote even in a case where the party states have created an impasse by a tie vote, it would appear that he has given insufficient attention to the lessons of history. In the case of a multi-state compact, it may be that the federal vote is unnecessary; perhaps the compact commission will progress, or settle to the lowest common denominator, at about the same speed, whether with or without a federal participating vote..$^{30}$ But a bi-state compact, without a federal tie-breaking vote, would be, as Governor Hearnes of Missouri has cogently stated, "worthless." ${ }^{30}$ The ominous possibility of a tie vote would always be present. An impasse means inaction, and nothing more.

There may be some bi-state metropolitan areas where the interests of the two states are so similar that the possibility of disagreement, and a tie vote, is slim. But one need not tax one's imagination to conjure up an image of a bi-state metropolitan area which has historically developed so that the major heavy industrial complex is in one state, and the greater share of the residential area is in the other state. In such a case, it is surely not improbable that the one state government would be more inclined than the other to resolve close questions in favor of delay in control, or relatively lax standards-in short, in favor of the industrial polluters-while the second state government would be more inclined to reflect the interests of its citizens, the breathers.

Nor is it unlikely that the tensions inherent in such a situation would be exacerbated by suspicions and charges of industrial piracy.

In such a metropolitan area, the probability of disagreement is all too apparent. It is, also, constantly present. Such disagreements would be expected to occur, not only in the fundamental tasks of establishing air quality goals and emission standards, but also in the day-to-day administrative and enforcement activities, such as granting or denying delays, accepting or rejecting excuses for excessive pollution, use of effective enforcement procedures and tools, and even in providing the energy and enthusiasm to be put into enforcement.

Perhaps the members of the commission would not permit such disagreements to come to the surface. History indicates that such a commission would tend, instead, to settle to the "lowest common denominator." But the absence of any effective tiebreaking method would emasculate any air pollution control program. It is difficult to conceive of a more clearly appropriate and needed function which the federal government could perform in this area than to furnish a third member of the commission, with a tie-breaking vote.

Moreover, absence of voting power in the federal representative on a compact

${ }^{88}$ Kansas-Missouri Air Quality Compact, Mo. ANN. Stat. $\$ 203.600$ (Supp. 1967).

${ }^{39}$ For discussion of the federal role in interstate compacts, see Grad, supra note 13 , and authorities there cited; Celler, Congress, Compacts and Interstate Authorities, 26 LAw \& Contemp. Prop. 682 (I96I).

${ }^{10} \mathrm{St}$. Louis Post-Dispatch, March 21, 1967, at I, col. 8. 
commission would ignore the federal interest. The interest of the federal government in the quality of the air which moves back and forth across state lines, injuring breathers in a state which lacks the power of redress, is inherent in our federal system. The Air Quality Act of 1967 appears to reinforce that interest.

Several other significant lessons might be learned from the history of the interstate compact.

First, it seems highly unlikely that an air pollution control compact will successfully clear the air unless the purpose of those who sponsor the compact, and of those persons who will ultimately serve on the compact commission, is simply to clear the air. If the real motive is to delay or forestall the advent of federal intervention, there will be no effective action. ${ }^{41}$

Second, it would be wise to spell out in unmistakable detail the geographical jurisdiction of any compact agency, to avoid litigation over jurisdictional issues. For example, Senate Bill 408, passed by the Missouri General Assembly in I967, specifically named the counties subject to the compact.

Third, to avoid financial strangulation, the compact commission should be given power to obtain necessary funds. This will not be easy to arrange, for the traditional method of financing such commissions is to depend upon appropriations from the state legislatures concerned, at least one of which may be less than sympathetic with the enforcement activities of the compact commission. There would appear to be no federal constitutional objection, however, to a provision authorizing the compact commission to allocate the cost of enforcement among the counties concerned, and levy assessments upon them.

Fourth, there is much to be said for the proposition that, as Senator Muskie has stated, the traditional compact "does not give adequate weight to local or metropolitan area participation in planning or implementing decisions."42 Again, there would appear to be no federal constitutional objection to a compact which authorized the compact commission to create, under its aegis, a regional authority to enforce air pollution control regulations throughout the region, on both sides of the state boundary, such authority to consist in part of local elected officials. ${ }^{43}$

Fifth, it would seem desirable to build into the compact the maximum flexibility. The grant of regulatory and enforcement powers must be categorical and un-

\footnotetext{
"The industrial ancestry of some of the presently proposed compacts might raise an eyebrow. See, e.g., Hearings on Air Pollution Compacts (Air Pollution-1968) Before the Subcomm. on Air and Water Pollution of the Senate Comm. on Public Works, 9oth Cong., 2d Sess., pt. I, at 30, 3I, 43I, 435, 44I, 442 (1968). See also Lieber, Controlling Metropolitan Pollution Through Regional Airsheds, I 8 J. ArR Pollution Control Ass's 86 (1968), reprinted in Hearings, id. at I41.

18 Procendings, stipra note 33 , at 598 .

" Compare the composition of the Delaware Valley Urban Area Compact Commission, N.J. Star. ANN. \$32:27-I (West Supp. 1968). Note the composition of the intrastate San Francisco Bay Area Air Pollution Control District, which includes elected officials from each county affected. CaL. HealTH \& SAFETY CODE $\$ \$ 24345,24351$ (West 1967). See Jones, The Organization of a Metropolitan Region, 105 U. PA. L. Rev. 538, 544 (1957); Advisory Comaisston on Intergovernmental Relations, Governmental Structure, Organization and Pzanning in Metropolitan Areas 29 (ig6i).
} 
mistakable; the minimum geographical jurisdiction should be specifically set forth. But, beyond the minimal requirements, flexibility is clearly desirable. If an effective form of federal-state cooperation is to be developed, as an alternative to centralized federal government, it seems likely that an adequate degree of sophistication will be achieved only as a result of trial and error. The first efforts, of which the Delaware River Basin Compact might be considered the prototype, will necessarily be faltering. A compact constrained by rigid limitations will very likely be doomed to failure.

At this writing, it remains to be seen whether Congress will approve any of the compacts before it, and on what terms such approval may be given. A study of history, however, offers little basis for optimism that any of the three proposed compacts will be notably successful in achieving clean air.

\section{Conclusion}

It may be that our state governments (or some of them) are too debilitated, too much dominated by the influence of special interest groups, to make a meaningful contribution to the solution of interstate air pollution problems. If any such contribution is to be made, it would appear that the only avenue offering any hope is through the interstate compact mechanism. It further appears that any such contribution must be made in partnership with the federal government, not in opposition to the federal government. The next few years will determine whether the state governments have matured sufficiently to follow this course, in the spirit that has come to be known as the spirit of "cooperative federalism," or whether the federal government will reluctantly be compelled to establish and enforce detailed emission standards for the interstate air quality regions. 